\title{
UI GREENMETRIC AND CAMPUS SUSTAINABILITY: A REVIEW OF THE ROLE OF AFRICAN UNIVERSITIES
}

\author{
ERNEST BABA ALI ${ }^{1} \&$ VALERY PAVLOVICH ANUFRIEV \\ Department of Environmental Economics, Ural Federal University named after the first \\ President of Russia BN Yeltsin, Russia
}

\begin{abstract}
The desire to combat the negative externalities of climate change and its variability has gained a lot of ground over the last few decades. This has resulted in the development of several approaches among which is the UI GreenMetric university ranking developed in 2010. In light of this, this article seeks to examine the performance of African higher education institutions on the ranking table and the impact they have had on their respective countries. To achieve this, this article compared performance scored between participating universities, carbon dioxide $\left(\mathrm{CO}_{2}\right)$ emission trends, and renewable energy consumption trends. The findings paint a picture of poor performance across each of the categories measured under the UI GreenMetric ranking. However, there was some marginal decline in $\mathrm{CO}_{2}$ emissions as well as an increase in renewable energy consumption for some participating countries. The findings reveal that participation of African universities in the ranking has been very low. Institutionalizing green campus initiatives by African governments to make it a must for a higher education institution to adopt such strategies was recommended. The study also recommends an increase in support for research in the area of green technologies, methods, and procedures in Africa so as to create enough awareness and education on the topic.

Keywords: Africa, environment, green campus, sustainable development, UI GreenMetricranking.
\end{abstract}

\section{INTRODUCTION}

Issues of sustainability have been of major concern to world leaders as achieving success in this regard will go a long way to help deal with the negative ramifications of climate change and variability. Over the last decade, the meaning and interpretation of the concept of sustainable development have raised serious debate among scholars. However, there appears to be a form of consensus in recent times [1]. The sustainability needs of a country have a direct relationship with its development. Achieving sustainability in a country's resource use will impact positively on the country's economic development drive. Of course, the sustainability status of a country to a very large extent influences its chances of achieving the Sustainable Development Goals (SDGs). Global concerns on the need to achieve sustainable development were featured strongly in the Millennium Development Goals (MDGs) and have again been the main point of focus in the SDGs. Indeed, whereas only Goal 7 of the MDGs was dedicated to dealing with issues pertaining to sustainable development, the whole of the SDGs focuses on attaining sustained development. Nonetheless, 11 out of the 17 SDGs specifically deal with different aspects of sustainability ranging from sustainable resource management to sustainable production patterns [2].

The responsibility of ensuring the sustainable use of resources in reducing environmental degradation or pollution so as to achieve sustainable development is often associated with sectors such as agriculture, land-use change and forestry, energy, and industrial processes. Indeed, the energy sector is projected to emit about $72 \%$ of all global emission. This consists of electricity and heat which constitute $31 \%$, transport $15 \%$, manufacturing and construction $12.4 \%$, other fuel combustion $8.4 \%$, and fugitive emissions $5.2 \%$ [3]. Interestingly, it is

1 ORCID:https://orcid.org/0000-0001-7053-3492 
acknowledged [4] that building and construction consume about 40\% of net global energy and release about a third of the world's total greenhouse gases. In sub-Saharan Africa (SSA), however, the land-use change and forestry emit about $40 \%$ of the continent's total greenhouse gases with energy and agriculture contributing about $31 \%$ and $21 \%$, respectively [5].

The impact of higher educational institutions on the environment and society has not gone unnoticed. It has been observed [1] that in China, for instance, the educational sector alone consumes about $40 \%$ of the country's public sector energy with each student consuming about four times that of residents. This gives an indication of the extent of impact the global education sector has on the world in terms of energy consumption which should not be ignored.

In response, the Green University System was adopted by higher education institutions across the globe to help deal with and improve sustainability issues on campuses by creating awareness among university management, students, and staff about environmental sustainability. As observed by Ragazzi and Ghidini [6], issues of sustainability in higher education were first brought up as far back as 1972 during the Stockholm Declaration. However, the involvement of higher education in environmental sustainability issues was officially documented in the 1990 Talloires Declaration. Again, the need to increase public education and awareness about sustainability issues was strongly re-echoed under the SDGs.

The concept of sustainability has become very important due to the growing recognition that harmful effects and economic costs of continued environmental degradation have increased over the last century [7]. The introduction of environment and sustainability-related programs in schools especially in higher educational institutions such as universities across the globe underscores the importance of environmental issues that have been raised by researchers and other stakeholders over the past few decades.

Having said that, this study examines the roles and responsibilities of higher education institutions and how prepared they are to take on the challenge of leading the way in attaining sustainability in their respective countries. The study seeks to address issues of the level of awareness with regard to the green university system. To achieve this, the concepts of the GreenMetric system and sustainable development are systematically reviewed.

\section{THE CONCEPT OF GREEN UNIVERSITY SYSTEM}

The backbone of the concept of sustainable development and related issues is the SDGs which came to life in 2016 on the completion of the MDGs. In 2012, the United Nations Conference on Sustainable Development was held and the SDGs were conceived. The purpose of the conference was to set universally accepted goals that urgently deal with challenges faced by the world's environment, politics, and economy. According to Tezel et al. [8], Agenda 21 highlights the importance of education as a medium that promotes sustainable development. Higher educational institutions have been acknowledged among the most important drivers of sustainable development and hence are expected to spearhead educational activities in green campus systems to enhance their influence on societies [8,9].

The concept of green university system broadly falls under the concept of sustainable development. The United Nations Conference on Environment and Development held in 1992 defined sustainable development as measures put in place to meet the environmental, economic, and social needs of this generation without jeopardizing the ability of future generations to satisfy their own needs.

By extension, the concept of a green university system or campus sustainability can be referred to as a group of strategies put in place to improve practices on university campuses to create awareness on sustainability and related issues among students, staff, and management. 


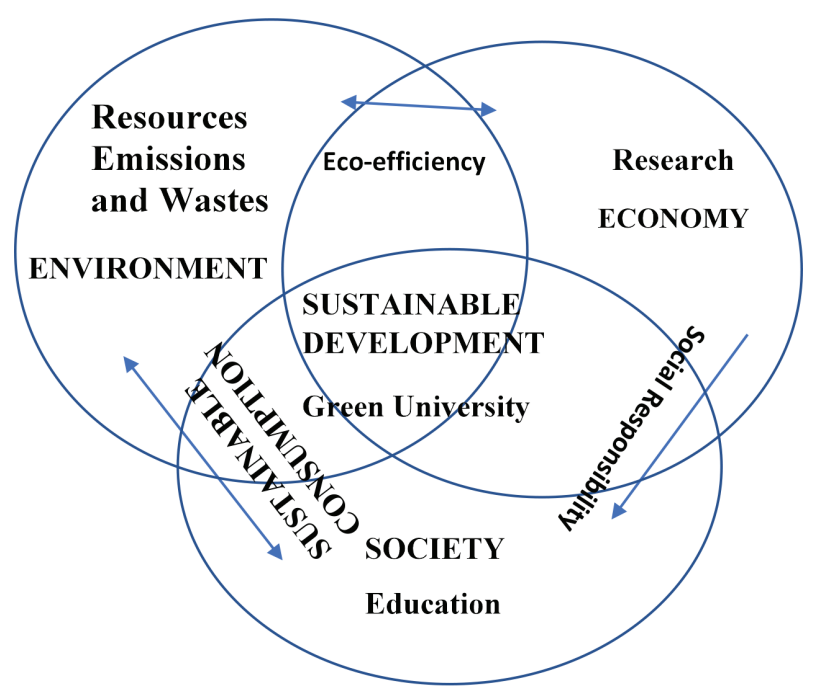

Figure 1: The linkages between sustainable development and Green University (Suwartha and Sari [12]).

Generally, the concept of green university draws its inspiration from the environmental sustainability concept; environment, economics, and society. Whereas the environmental aspect consists of natural resource use, environmental management, and pollution prevention, the economic aspect comprises a profit and costing. Education, community, and social involvement make up the social aspect [10]. Adopting the concept of sustainable development, Adams [11] and Suwartha and Sari [12] drew a link between sustainable development and sustainable university (green university) (Fig. 1).

According to Yuan et al. [1], the term green university can be misleading due to its apparent bias toward ecology. However, given the multidimensional nature of the term as portrayed in Fig. 1, it is fair to associate the meaning of green university to 'sustainable university'. This means that 'green university' looks beyond environmental aspects of sustainability and extends to issues of research, development, education, and staff rewards among others [1]. Abubakar et al. [13] noted that achieving an effective green university system is almost impossible without the cooperation of key stakeholders like students, staff, management, funding agencies, and the society as a whole. Since the conception of this idea and the signing of the 1990 Talloires Declaration, 507 universities from 59 countries worldwide have signed as of March 2019.

\section{GREENMETRIC SYSTEM AND SUSTAINABILITY}

The signing of the 1990 Talloires Declaration was the beginning of a series of efforts to address environmental issues in higher education institutions. The aim was basically to get higher education institutions to implement a green campus program such as the construction of new green buildings, the development of advanced methods to reduce water and electricity consumption, as well as innovative ways of collecting, distributing, and disposing of wastes. This gave birth to a number of interventions among stakeholders such as the emergence of higher education ranking tables like those mentioned by Lauder et al. [14]. These ranking tables include but are not limited to the Sustainability, Tracking, Assessing and Rating System (STARS), the College Sustainability, Report Card, GREENSHIP. According to Lukman 
et al. [15], these interventions also emerged from both the private and government sectors as well as professional bodies. However, some of these ranking methodologies had their shortfalls with regard to their weighting and the type of indicators [16]. This raised additional environmental sustainability concerns among university management about the sustainability efforts of organizations.

Owing to this, by 2010, pragmatic steps to dealing with sustainability issues on campuses emerged. This led to the creation of the UI GreenMetric system by the University of Indonesia (UI) [17]. Under this approach, higher educational institutions across the globe are now ranked according to their performance in the implementation of campus sustainability. Performances of these institutions are measured against well-defined and globally accepted indicators which are placed under six broad categories [6]. These six broad categories are environment and infrastructure, energy and climate change, waste, water, transport and education, and research [6]. According to Hamzah et al. [18], these categories as spelt out by the UI GreenMetric system are well aligned with the SDGs adopted by the United Nations (Table 1). Similarly, Suwartha and Sari [12] affirmed that UI GreenMetric methodology was aligned to the Berlin

Table 1: Nexus between UI GreenMetric and the sustainable development goals (SDGs).

\begin{tabular}{|c|c|c|}
\hline $\begin{array}{l}\text { UI GreenMetric } \\
\text { category }\end{array}$ & SDG & $\begin{array}{l}\text { SDG } \\
\text { number }\end{array}$ \\
\hline \multirow[t]{2}{*}{$\begin{array}{l}\text { Environment and } \\
\text { infrastructure }\end{array}$} & $\begin{array}{l}\text { Build resilient infrastructure, promote inclusive } \\
\text { and sustainable industrialization, and foster } \\
\text { innovation }\end{array}$ & 9 \\
\hline & $\begin{array}{l}\text { Make cities and human settlements inclusive, safe, } \\
\text { resilient, and sustainable }\end{array}$ & 11 \\
\hline \multirow[t]{2}{*}{$\begin{array}{l}\text { Energy and climate } \\
\text { change }\end{array}$} & $\begin{array}{l}\text { Ensure access to affordable, reliable, sustainable, } \\
\text { and modern energy for all }\end{array}$ & 7 \\
\hline & $\begin{array}{l}\text { Take urgent actions to combat climate change and } \\
\text { its actions }\end{array}$ & 13 \\
\hline \multirow[t]{2}{*}{ Waste } & $\begin{array}{l}\text { Ensure healthy lives and promote well-being for } \\
\text { all at all ages }\end{array}$ & 3 \\
\hline & $\begin{array}{l}\text { Conserve and sustainably use oceans, seas, and } \\
\text { marine resources for sustainable development }\end{array}$ & 14 \\
\hline Water & $\begin{array}{l}\text { Ensure availability and sustainable management of } \\
\text { water and sanitation for all }\end{array}$ & 6 \\
\hline \multirow[t]{2}{*}{ Transport } & $\begin{array}{l}\text { Take urgent actions to combat climate change and } \\
\text { its actions }\end{array}$ & 13 \\
\hline & $\begin{array}{l}\text { Protect, restore, and promote sustainable use of } \\
\text { terrestrial ecosystems, sustainably manage } \\
\text { forests, combat desertification, halt and reverse } \\
\text { land degradation, and halt biodiversity loss }\end{array}$ & 15 \\
\hline Education and research & $\begin{array}{l}\text { Ensure inclusive and equitable quality education } \\
\text { and promote lifelong learning opportunities for all }\end{array}$ & 4 \\
\hline
\end{tabular}


Principles in order to easily evaluate their performance and quality. The Berlin Principles are a set of 'good and quality practices in higher institution ranking' which were avowed by international experts brought together by the United Nations Educational, Scientific and Cultural Organization (UNESCO) [6].

Over the years, the ranking has been revised and this has resulted in an improvement in the original version of the UI GreenMetric methodology. This revision was based on feedback received from the participating universities. These revisions lead to an increase in the number of indicators from 23 in 2010 to 42 in 2011 [12]. However, the number of indicators was reduced to 39 in 2015 and 38 in 2016 [6]. Similarly, the weighting points of the 2011 revised UI GreenMetric has also changed over the years (Table 2). The education category, even though absent in the initial version of UI GreenMetric, was later included in the 4th version due to the wide acceptance of the important role education plays in sustainable development $[19,20]$.

The global acceptance of the UI GreenMetric methodology since its inception and the recognition that it is the first of its kind to try to produce a sustainable university ranking [21], underscores its significance to winning the sustainability fight on campuses. Nevertheless, experts believe, the methodology requires some improvement. For instance, Ragazzi and Ghidini [6] identified some challenges and suggested some solutions to dealing with the problems they identified. These include but are not limited to the absence of a threshold, scoring bands, and relativity of scores. They, for example, argued that due to the absence of a threshold, any university can enter the ranking even if they do not guarantee any achievement in campus sustainability. It was then suggested that with the inclusion of a threshold, the methodology would first and foremost serve as a guarantee for paying minimal attention to campus sustainability while at the same time serving as 'certificate of sustainability'. On the issue of the absence of scoring bands, they were of the view that with current scores assigned on the basis of environmental performance, it was difficult to tell the level of sustainability achieved by the participating institutions. It was suggested that the introduction of scoring

Table 2: Categories used in ranking and their weighting (Source: Suwartha and Sari [12]; UI GreenMetric [10]).

\begin{tabular}{|c|c|c|c|c|c|c|c|}
\hline \multirow[b]{2}{*}{ No } & \multirow[b]{2}{*}{ Category } & \multicolumn{3}{|c|}{2011} & \multicolumn{3}{|c|}{2018} \\
\hline & & $\begin{array}{l}\text { No. of } \\
\text { indicators }\end{array}$ & Points & $\begin{array}{l}\% \text { of } \\
\text { total } \\
\text { points }\end{array}$ & $\begin{array}{l}\text { No. of } \\
\text { indicators }\end{array}$ & Points & $\begin{array}{l}\% \text { of } \\
\text { total } \\
\text { points }\end{array}$ \\
\hline 1 & $\begin{array}{l}\text { Setting and infra- } \\
\text { structure }\end{array}$ & 20 & 2400 & 24 & 6 & 1500 & 15 \\
\hline 2 & $\begin{array}{l}\text { Energy and climate } \\
\text { change }\end{array}$ & 10 & 2800 & 28 & 8 & 2100 & 21 \\
\hline 3 & Waste & 5 & 1500 & 15 & 6 & 1800 & 18 \\
\hline 4 & Water & 3 & 1500 & 15 & 4 & 1000 & 10 \\
\hline 5 & Transport & 4 & 1800 & 18 & 8 & 1800 & 18 \\
\hline \multirow[t]{2}{*}{6} & Education & - & - & - & 7 & 1800 & 18 \\
\hline & Total & 42 & 10000 & 100 & 39 & 10000 & 100 \\
\hline
\end{tabular}


bands would allow experts to easily read, interpret, and appreciate the degree of sustainability of participating institutions.

\section{SUSTAINABLE DEVELOPMENT EFFORTS IN HIGHER EDUCATION INSTITUTIONS IN AFRICA}

It is without a doubt that the education sector, particularly higher education institutions, have a direct and indirect impact on both the local and international environment. Globally, it is accepted that universities have some negative impacts on the environment such as improper waste management, inefficient energy and water consumption, and emission of greenhouse gases from campus transport systems. Leal Filho et al. [9] opine that universities present a viable platform for attaining sustainability due to their ability to research into new technologies and methods. According to Hooi et al. [22], the stability of higher educational institutions enjoyed by way of their long-term thinking, viz, research and institutional goals, position them well to incorporate sustainability issues into their curriculum. This places the responsibility of leading the sustainability drive on the shoulders of higher institutions [23].

Efforts by higher education institutions in Africa just like many other institutions all over the world can be traced back to the 1990 Talloires Declaration. As indicated in Talloires Declaration [24], of the 507 signatories to the declaration, only 18 were institutions from Africa. These include:

1. Ghana: University of Ghana, Legon, and Valley View University, Accra.

2. Kenya: Kenya Marine and Fisheries Institute, Moi University, Eldoret, and University of Nairobi, Nairobi.

3. Malawi: University of Malawi System: Bunda College of Agriculture, Chancellor College, Zomba, Kamuzu College of Nursing, Medical College, and Polytechnic Institute.

4. Nigeria: Ahmadu Bello University, Zaria, and University of Ibadan, Ibadan.

5. South Africa; Rhodes University, Cape Province, University of Cape Town, Cape Town, University of Natal, Durban, University of the Western Cape, Bellville, and University of Witwatersrand, Johannesburg.

6. Zimbabwe: University of Zimbabwe, Harare.

Nevertheless, the commitment to attain environmental sustainability transcends the borders of signing a mere declaration to actually implementing effective and efficient strategies that deal with the problem. Moving beyond the declaration, little effort has been put in by high education institutions in Africa to deal with the issues of sustainability. Since the inception of the UI GreenMetric in 2010, only 16 high educational institutions from Africa have featured by appearing 47 times in the ranking. Whereas no African universities featured in the initial ranking, one (the University of Kwazulu Natal in South Africa) featured from 2011 to 2013. The number of institutions slightly increased from five in 2014 to six in 2015 with the American University in Cairo, Kafrelsheikh University, Egypt, University of Kwazulu Natal, Minia University, Egypt, University of South Africa, and Polytechnic of Namibia making the 2015 ranking list. The years 2016-2018 recorded the highest number of African institutions (11) on the ranking list (Fig. 2). These include:

1. Egyptian institutions: Kafrelsheikh University, American University in Cairo, South Valley University, and Minia University.

2. South Africa: the University of Kwazulu Natal and University of South Africa. 


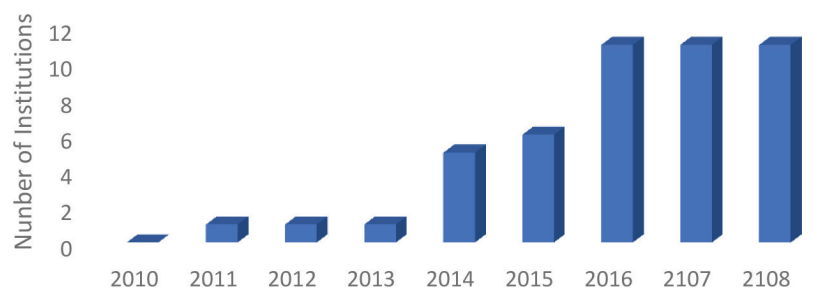

Figure 2: Number of African institutions in the UI GreenMetric Ranking list from 2010 to 2018 (UI GreenMetric [25]).

3. Morocco: Universite Cadi Ayyad and Al Akhawayn University in Ifrane.

4. Tunisia: Universite de Monastir and Universite de Sousse.

5. Algeria: Abou Bekr Belkaid Tlemcen.

6. Ghana: University of Education, Winneba.

7. Nigeria: University of Ota.

8. Namibia: Polytechnic of Namibia.

Comparing the performance of four universities in the 2018 ranking gives a clear indication of underperformance in all categories of the UI GreenMetric ranking (Table 3). Out of a maximum point of 1500 representing $15 \%$ of the total score for 'setting and infrastructure', the University of Kwazulu Natal, American University in Cairo, University of Education, Winneba, and Universite Abou Bekr Balkaid, Tlemcen, scored 700, 950, 350, and 275, respectively. These translates into only $7 \%, 9.5 \%, 2.8 \%$, and $2.75 \%$, respectively. Although the performances under the 'energy and climate change' category for the four universities were also far below the recommended score (2100 points) which represented $21 \%$ of the total score, they appeared to perform better here on average than under the rest of the indicators.

Table 3: 2018 UI GreenMetric ranking and scores of selected African universities (UI GreenMetric [25]).

Universite

\begin{tabular}{lcccc} 
UI GreeMetric ranking & $\begin{array}{c}\text { University } \\
\text { of Kwazulu }\end{array}$ & $\begin{array}{c}\text { American } \\
\text { University of }\end{array}$ & $\begin{array}{c}\text { University of } \\
\text { Education, }\end{array}$ & $\begin{array}{c}\text { Abou Bekr } \\
\text { category }\end{array}$ \\
\hline Natal & Cairo & Winneba & Tlemcen \\
\hline Setting and infrastructure & 700 & 136 th & 632 nd & 683 rd \\
Energy and climate change & 550 & 1125 & 350 & 275 \\
Waste & 525 & 1050 & 925 & 600 \\
Water & 125 & 750 & 300 & 0 \\
Transport & 325 & 1025 & 525 & 0 \\
Education and research & 500 & 1200 & 475 & 675 \\
Total & 2725 & 6100 & 2975 & 2300 \\
\hline
\end{tabular}


The ranking further shows the relative strengths and weaknesses of participating institutions. For instance, while the University of Kwazulu Natal scored high points (700) in 'setting and infrastructure' and low points (125 representing 1.25\%) in the 'water' category, the American University in Cairo scored high points (1200 representing 12\%) in the 'education and research' category and low points (750 which constitute $7.5 \%)$ in the 'water' category. Also whereas University of Education, Winneba in Ghana performed better ( 925 constituting 9.5\%) in 'energy and climate change' they performed poorly in the 'waste' category. Universite Abou Bekr Belkaid Tlemcen, on the other hand, performed abysmally in both the 'waste' and 'water' categories but recorded its highest score (750) in 'education and research'. The total points accrued by each of the four institutions indicate that the University of Kwazulu Natal, American University in Cairo, University of Education, Winneba, and Universite Abou Bekr Belkaid Tlemcen scored 27.25\%, 61\%, 29.75\%, and 23\%, respectively.

\subsection{Impact of UI GreenMetric Ranking on national carbon dioxide $\left(\mathrm{CO}_{2}\right)$ emissions}

Climate change is fast becoming the defining global issue in recent time. As global greenhouse gas (GHG) emissions increase and global temperatures rise, life, as we know it, is under threat especially in most developing countries [26].

Even though climate change effects on developing economies cannot be underscored, an argument can also be made for the effect of anthropogenic activities on the former. Thus, one major contributing factor is the increase in $\mathrm{CO}_{2}$ emissions as a result of population growth, a surge in energy demand, increasing economic growth, and growth in agricultural production to achieve food security [27-29]. For decades, there has been a surge in the use of fossil fuels as a source of energy supply thereby resulting in exponential growth of $\mathrm{CO}_{2}$ emissions.

Therefore, to assess the impact of UI GreenMetric ranking on higher educational institutions in Africa, the study analyzed $\mathrm{CO}_{2}$ emission trends of participating African countries from 2010 to 2017 (Fig. 3). In the years preceding the commencement of the UI GreenMetric ranking, South Africa recorded an increasing trend in $\mathrm{CO}_{2}$ emissions (2005-2009). However, between 2010 and 2017, $\mathrm{CO}_{2}$ emissions recorded a relatively downward trend. Thus, whereas emissions increased from 415 million tonnes of $\mathrm{CO}_{2}$ emissions in 2005 to 501 million tonnes in 2009, between 2010 and 2017, emissions decreased from 472 million tonnes to 456 million tonnes. The period of decline in emission coincides with South Africa's participation in the UI GreenMetric ranking. Of the participating African countries, South Africa, even though represented by only two universities, has been the most consistently appearing in eight versions of the ranking (from 2011 to 2018).

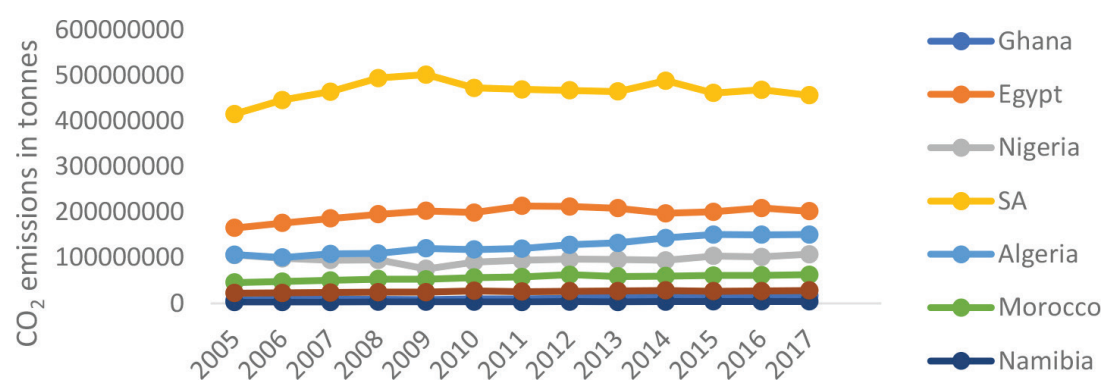

Figure 3: Emission trends of some participating countries of the UI GreenMetric Ranking (Our World in Data [30]). Note: SA represents South Africa. 
Similarly, $\mathrm{CO}_{2}$ emissions in Egypt increased from 165 million tonnes in 2005 to 202 million tonnes in 2009. Although Egypt did not participate in the 2010 ranking, emission slightly decreased to 199 million tonnes. It is worth noting that Egypt only started participating in the ranking from 2014 with only one University (Kafrelsheikh University) representing the country. However, in 2017, the number of Egyptian universities increased to four. This could possibly be the reason for the reduction in the $2017 \mathrm{CO}_{2}$ emissions. Regardless of Morocco's participation in the UI GreenMteric ranking between 2016 and 2018, the country's emissions recorded an increasing trend within the period. This is not surprising given that for each of the years 2016 and 2017, Morocco was represented by one university. Their impact could be considered to be insignificant compared with having multiple institutions being featured in a given year.

Tunisia, Algeria, Nigeria, Namibia, and Ghana recorded an increasing trend for the periods within which they featured in the ranking. All these countries for each of the years they featured were represented by a university each explaining the reason for the increase rather than a decline in the levels of $\mathrm{CO}_{2}$ emissions. Additionally, whereas Algeria and Ghana featured in 2016, 2017, and 2018 rankings, Tunisia only featured in the 2017 and 2018 ranking. In contrast, Namibia was represented in the rankings from 2014 to 2018 with Nigeria appearing only in the 2016 ranking.

\subsection{UI GreenMetric ranking participation and renewable energy consumption}

Sources of renewable energy such as solar, wind, hydropower, modern biofuels, geothermal, wave, and tidal energies are capable of naturally replenishing themselves without depleting. This implies that renewable energy sources are sustainable in nature and play a massive role in cutting down on national and global emission of greenhouse gases.

Increasing global population coupled with the growing demand for energy has resulted in the continuous dependence on fossil fuel to generate energy. This has led to several challenges ranging from environmental issues to fluctuation in global fuel prices which affect economic progress. It has been acknowledged [31] that these challenges, if not addressed, pose serious threats to societies. Energy experts and global stakeholders strongly believe that a transition from the use of fossil fuels to renewable energy sources has the potential to help achieve economic, environmental, and social sustainability [32] as well as the efficient use of energy.

Given that a regular energy supply plays a critical role in boosting economic development, it is imperative that global economies pay more attention to renewable energy sources and their efficient utilization. The relationship between some selected African countries that

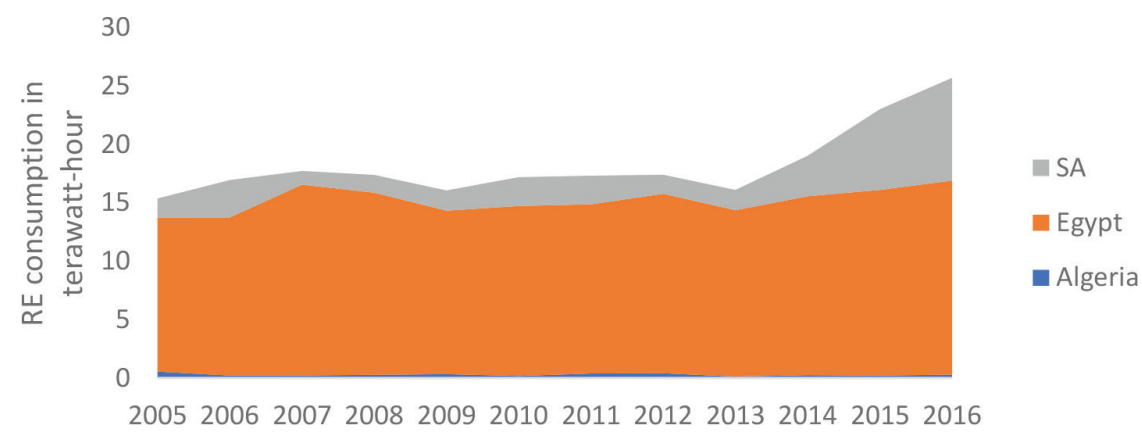

Figure 4: Renewable energy consumption trends of selected African countries in the UI GreenMteric ranking (Our World in Data [30]). Note: SA represents South Africa; $\mathrm{RE}$ represents renewable energy. 
participated in the UI GreenMetric ranking and their renewable energy consumption were analyzed (Fig. 4).

Generally, renewable energy consumption for Algeria, Egypt, and South Africa has fluctuated over the years. Clearly, the average renewable energy consumption in terawatt per hour for South Africa during the years of participating was higher than that of the years preceding it. Thus, whereas the average renewable energy consumed between 2005 and 2009 was $1.85 \mathrm{TW} / \mathrm{h}, 2010-2016$ recorded a value of $3.92 \mathrm{TW} / \mathrm{h}$. Indeed, renewable energy consumption drastically increased from $2.47 \mathrm{TW} / \mathrm{h}$ in 2010 to $8.8 \mathrm{TW} / \mathrm{h}$ in 2016. Similarly, the highest renewable energy consumption $(16.6 \mathrm{TW} / \mathrm{h})$ for Egypt was recorded in 2016 during which time four Egyptian universities featured in the UI GreenMetric ranking. Interestingly, 2013 recorded the lowest value (14.25 TW/h) for the period 2010-2016. However, it is worth noting that no Egyptian university participated in the ranking that year. This could possibly be the reason for the decline. Contrary to the trend of South Africa and Egypt, Algeria recorded a steady decline in renewable energy consumption between 2012 and 2016. Algeria first participated in the ranking in 2016 with only one university (University of Tlemcen).

\section{CONCLUSION}

Efforts to transition from unsustainable university campus systems to more sustainable ones (green campuses) have received a lot of attention globally in recent times. The adoption of green technologies or strategies is widely accepted as the way forward to achieving this goal. However, issues of campus sustainability and the adoption of green methods or strategies are still at the budding stage in Africa. The UI GreenMetric ranking since its inception has been widely regarded as the first of its kind that seeks to deal with sustainability issues on university campuses. Indeed, all the six categories of the UI GreenMetric are well imbedded in global sustainability goals. Therefore, participating in the UI GreenMetric ranking and being rated high goes a long way not only to sustainably improve the immediate university campus environment and immediate society but also indirectly support the national and global discourse by helping to attain global sustainability in the long run. To this end, this article attempts to understand the efforts made by high education institutions in developing countries, particularly those in Africa toward university campus sustainability. To accomplish this, the study qualitatively reviewed studies regarding the subject. Information, especially data regarding the nexus between sustainable campus development and environmental sustainability in Africa, in particular, is still limited. Regardless, university campus sustainability development in its complete lifecycle produces zero or reduced net emissions thereby reducing global emissions and hence global climate change.

The study presented useful information on university campus sustainability efforts; the interrelationship between the UI GreenMetric and global sustainability; improvements made in the UI GreenMetric methodology over the years, efforts by African institutions toward campus sustainability, the nexus between campus sustainability and national $\mathrm{CO}_{2}$ emissions and renewable energy consumption in Africa. The findings of the study reveal:

1. There is a strong interconnection between the GreenMetric methodology and United Nations global sustainable goals (SDGs).

2. Not enough attention has been given to research and education on sustainability issues in African higher educational institutions. 
3. Participating in the UI GreenMetric ranking has the potential of helping to reduce national $\mathrm{CO} 2$ emissions as in the case of South Africa and Egypt.

4. $\mathrm{CO} 2$ emissions in South Africa decreased from 472.5 million tonnes in 2010 to 456.3 million tonnes in 2017, the period within which South African universities featured in the UI GreenMetric ranking.

5. There is a positive relationship between participating in the UI GreenMetric ranking and renewable energy consumption in Africa. This implies that in relative terms, African universities were performing well in the energy and climate category of the UI GreenMetric ranking system.

The study makes the following recommendations to help improve university campus sustainability in Africa:

1. Issues of university campus sustainability in Africa must not be only the priority of higher education institutions but also that of successive governments. This can be done by incorporating green campus policies in environmental development plans that will make it compulsory for higher educational institutions to green their campuses.

2. Increase discussions on green campus technologies among experts and stakeholders in Africa. This will help in developing cheaper climate-friendly technologies that suit the African setting.

3. Increase support for research in the area of green technologies, methods, and procedures so as to create enough awareness and education on the topic.

4. Higher educational institutions in Africa should partner with their counterparts in the developed world that are doing well in the sustainable campus drive. This will help them to learn and appreciate efforts toward attaining this goal.

\section{REFERENCES}

[1] Yuan, X., Zuo, J. \& Huisingh, D., Green universities in China-what matters? Journal of Cleaner Production, 61, pp. 36-45, 2013. https://doi.org/10.1016/j.jclepro.2012.12.030

[2] Resolution adopted by the General Assembly on 25 September 2015. United Nations, https://www.un.org/ga/search/view_doc.asp?symbol=A/RES/70/1\&Lang=E. Accessed on: 08 September. 2019.

[3] Global emissions: Centre for Climate and Energy Solutions [CCES]. https://www.c2es. org/content/international-emi ssions/. Accessed on: 23 August 2019.

[4] Buildings and climate change-Summary for decision-Makers.2009. United Nation Environmental Programme, https://www.greeningtheblue.org/sites/default/files/Buildings\%20and\%20climate\%20change_0.pdf. Accessed on: 23 September 2019.

[5] Historical greenhouse gas emissions: Climate watch. https://www.climatewatchdata. org/ghgemissions?breakBy=sector\&chartType=percentage. Accessed on 23 August 2019.

[6] Ragazzi, M. \& Ghidini, F., Environmental sustainability of universities: Critical analysis of a green ranking. Energy Procedia, 119, pp. 111-120, 2017. https://doi.org/10.1016/j. egypro.2017.07.054

[7] Robinson, J.B., Francis, G., Lerner, S. \& Legge, R., Defining a sustainable society. Life in 2030: Exploring sustainable future for Canada, ed. J.B. Robinson, University of British Colombia Press: Vancouver, Canada, pp. 26-52, 1996. 
[8] Tezel, E., Ugural, M. \& Giritli, H., Towards green campus: Students' perception and expectations. 5th International Project and Construction Management Conference, Cyprus International University, North Cyprus, 2018.

[9] Leal Filho, W., Shiel, C., do Paço, A. \& Brandli, L., Putting sustainable development in practice: Campus greening as a tool for institutional sustainability efforts. Sustainability in higher education. Chandos Publishing, pp. 1-9, 2015.

[10] UI GreenMetric World University Rankings, Sustainable University in a Changing World: Lessons, Challenges and Opportunities, University of Indonesia, Indonesia, 2019.

[11] Adams, W.M., The future of sustainability: Re-thinking environment and development in the twenty-first century, Report of the IUCN renowned thinkers meeting, 29-31 January, 2006.

[12] Suwartha, N. \& Sari, R.F., Evaluating UI GreenMetric as a tool to support green universities development: Assessment of the year 2011 ranking. Journal of Cleaner Production, 61, pp. 46-53, 2013.

[13] Abubakar, I., Al-Shihri, F. \& Ahmed, S., Students' assessment of campus sustainability at the University of Dammam, Saudi Arabia. Sustainability, 8(1), pp. 59, 2016.

[14] Lauder, A., Sari, R.F., Suwartha, N. \& Tjahjono, G., Critical review of a global campus sustainability ranking: GreenMetric. Journal of Cleaner Production, 108, pp. 852-863, 2015.

[15] Lukman, R., Krajnc, D. \& Glavic, P., University ranking using research, educational and environmental indicators. Journal of Clean Production, pp. 1-10, 2009. doi:10.1016/j. jclepro.2009.09.015

[16] Marginson, S., Global university rankings: Implications in general and for Australia. Journal of Higher Education Policy and Management, 29(2), pp. 131-134, 2007.

[17] Kingston, K., Cassil, B. \& Wilson, B., Inspiring a sustainable culture at a school or university, American School \& University, Asumag.com, pp. 24-26, 2017.

[18] Hamzah, R.Y., Alnaser, N.W. \& Alnaser, W.E., Accelerating the transformation to a green university: University of Bahrain experience. E3S Web of Conferences, $\mathbf{4 8}$, article number 06002, 2018.

[19] Lozano, F.J., \& Lozano, R., Developing the curriculum for a new Bachelor's degree in engineering for sustainable development. Journal of Clean Production, 64, pp. 136-146, 2014.

[20] Lozano, R., Ceulemans, K. \& Scarff Seatter, C., Teaching organizational change management for sustainability: designing and delivering a course at the University of Leeds to better prepare future sustainability change agents. Journal of Clean Production, 106, pp. 205-215, 2015.

[21] Grindsted, T.S., Sustainable universities - from declarations on sustainability in higher education to national law. Environmental Economics, 2, pp. 29-36, 2011.

[22] Hooi, K.K, Hassanb, F. \& Mat, M.C., An exploratory study of readiness and development of green university framework in Malaysia. Procedia-Social and Behavioral zSciences, 50, pp. 525-536, 2012.

[23] Saadatian, O., Sopian, K.B. \& Salleh, E., Adaptation of sustainability community indicators for Malaysian campuses as small cities. Sustainable Cities and Society, $\mathbf{6}$, pp. 40-50, 2013.

[24] Association of University Leaders For A Sustainable Future. Talloires Declaration Signatories List. 2019. http://ulsf.org/96-2/\#Ghana/. Accessed on: 1 Sept. 2019.

[25] UI GreenMetric. World University Ranking 2010 to 2018. http://greenmetric.ui.ac.id/ archive-ranking/. Accessed on: 15 August 2019. 
[26] Appiah, K., Du, J., Musah, A.A., \& Afriyie, S., Investigation of the relationship between economic growth and carbon dioxide $\left(\mathrm{CO}_{2}\right)$ emissions as economic structure changes: evidence from Ghana. Resources and Environment, 7(6), pp. 160-167, 2017.

[27] Asumadu-Sarkodie S. \& Owusu, P.A., A review of Ghana's energy sector national energy statistics and policy framework. Cogent Engineering, 3(1), Article 1155274, 2016.

[28] Shahbaz, M., Khan, S., Ali, A. \& Bhattacharya, M., The impact of globalization on $\mathrm{CO}_{2}$ emissions in China. The Singapore Economic Review, 62(4), pp. 929-935, 2017.

[29] Sarkodie, S.A., Crentsil, A.O. \& Owusu, P.A., Does energy consumption follow asymmetric behavior? An assessment of Ghana's energy sector dynamics. Science of the Total Environment, 651, pp. 2886-2889, 2019.

[30] Our World in Data. Annual share of $\mathrm{CO}_{2}$ emissions. 2019. https://ourworldindata.org/ search?q=global+CO2+emissions. Accessed on: 19 Sept. 2019.

[31] United Nations Framework Convention on Climate Change. Adoption of the Paris agreement, 2015. http://unfccc.int/resource/docs/2015/cop21/ eng/109r01.pdf. Accessed on: 1 September 2019.

[32] Owusu, P.A. \& Asumadu-Sarkodie, S., A review of renewable energy sources, sustainability issues and climate change mitigation. Cogent Engineering, 3(1), Article 1167990, 2016. 